\title{
ANALISIS METODOLOGIS-FILOSOFIS KONSEP TAFSIR JAMÂL AL-BANNÂ
}

\author{
Mukhammad Zamzami \\ Fakultas Ushuluddin dan Filsafat UIN Sunan Ampel \\ Jl. Ahmad Yani No. 117, Surabaya, Jawa Timur, 60237 \\ e-mail: zamzami81@yahoo.com
}

\begin{abstract}
Abstrak: Artikel ini mencoba untuk mengulas metode penafsiran Jamâl al-Bannâ secara metodologis dan filosofis. Dimulai dengan upaya untuk mendekonstruksi interpretasi hasil dari semua mufasir klasik, Jamâl al-Bannâ mengusulkan tiga tahap dalam penafsiran al-Qur'an, yaitu pendekatan seni, pendekatan psikologis, dan pendekatan rasional. Ketiganya merupakan tahapan hierarkis untuk bisa sampai pada sebuah penafsiran. Setelah bisa sampai pada tahap penafsiran, Jamâl al-Bannâ tidak merekomendasikan metode tertentu atau membatasi ilmu pengetahuan tertentu sebagai metode analisa penafsiran. Ia menolak jika salah satu metode tertentu memiliki garansi sebagai satu-satunya cara untuk menemukan kebenaran, karena al-Qur'an tidak harus dibatasi. Dalam sosiologi pengetahuan, pemikirannya mirip dengan Against Method (Anarkisme Metode) Paul K. Feyerabend. Bagi Jamâl al-Bannâ, manusia sangat otonom dan bebas untuk menafsirkan selama itu sejalan dengan prinsip-prinsip humanis dan universal yang terkandung dalam al-Qur'an.
\end{abstract}

\begin{abstract}
Methodological and Philosophical Analysis of Jamâl al-Bannâ's Qur'anic Exegesis. This article seeks to analyze the method of Jamâl al-Bannâ's interpretation. Beginning with an attempt to deconstruct the interpretation of the results of all classical mufassir, Jamâl al-Bannâ proposed three stages in the interpretation of the Qur'an that include such approaches as stylistic, psychological, and rational method. All three approaches are utilized hierarchically in order to come to an interpretation. At the rational stage of Qur'anic exegesis, Jamâl al-Bannâ didn't recommend a specific method or limit the science to a particular method. He refused that one particular method has the warranty as the only interpretation to seek the way for the truth, because the Qur'an should not be restricted. In the sociology of knowledge, his thinking is similar to that of Paul K. Feyerabend's Against Method. According to Jamâl al-Bannâ, human beings are very autonomous and free to interpret the Qur'an as long as it is in line with the principles of humanistic and universal values as enshrined there in.
\end{abstract}

Kata Kunci: Tafsir al-Qur’an, Jamâl al-Bannâ, pendekatan seni, metode penafsiran 
MIQOT Vol. XXXVIII No. 2 Juli-Desember 2014

\section{Pendahuluan}

Al-Qur'an adalah sumber pengetahuan yang diwariskan oleh sejarah intelektual Muslim. Sejak Muhammad hadir, al-Qur'an selalu menghiasi kecerdasannya baik secara intelektual maupun spiritual, sehingga al-Qur'an eksis memberikan pewarnaan interpretasi demi kemaslahatan umat. Al-Qur'an merupakan petunjuk bagi manusia yang berakal untuk menyelesaikan problematika kehidupan sehari-hari sesuai dengan ruang dan waktu. Diakui atau tidak, wahyu adalah bahasa Tuhan yang transendental dan sakral, sedangkan tafsir adalah bahasa manusia ditafsirkan secara imanen oleh para mufassir sesuai dengan pengalaman hidup masing-masing. Kemunculan para penafsir dalam menafsirkan alQur'an dengan penawaran metodologi yang beragam adalah bukti adanya parameter yang dimiliki setiap penafsir. Sesungguhnya, para penafsir menyadari bahwa jika alQur'an tidak ditafsirkan berdasarkan pada konteks perkembangan dan peradaban manusia, maka al-Qur'an akan mengalami kemandekan intelektual, sehingga pesan-pesan alQur'an menjadi tertutup. Senada apa yang dikatakan oleh 'Alî b. Abî Thâlib bahwa "tanpa manusia, al-Qur'an tidak bisa berbicara apa-apa". Dengan demikian, fungsi penafsiran al-Qur'an harus didasarkan pada problem keagamaan kontemporer dan tidak harus merujuk pada khazanah pemikiran klasik, akan tetapi tawaran penafsiran yang kontekstual harus terus dilakukan.

Di era kontemporer ini, geliat pemikir pembaru Muslim yang sudah menawarkan gagasan baru terhadap penafsiran al-Qur'an, tidak terkecuali Jamâl al-Bannâ. Jika Hasan Hanafî (1.1935) mengembangkan tafsir realis ${ }^{1}$, Fazlur Rahman (1919-1998) dengantafsir tematik-kontekstual dengan teori Double Movement ${ }^{2}$, Muhammad Arkûn (1. 1928) dengan trilogi linguistik, antropologis dan historis ${ }^{3}$, Nasr HâmiđAbû Zayd (1943-2010) dengan pendekatan sastra ${ }^{4}$, serta Muhammad Shahrûr (1-1938) dengan lingusitik-strukturalisnya ${ }^{5}$, maka kontribusi Jamâl al-Bannâ hadir dengan gagasan tafsir humanisnya.

Artikel ini secara khusus akan mengupas metode penafsiran Jamâl al-Bannâ yang menawarkan tiga tahapan penafsiran dalam menyelesaikan problem-problem kemanusiaan yang terjadi di tengah-tengah masyarakat. Pendekatan seni, psikologi, dan rasional diwacana-

${ }^{1}$ M. Mansur, "Metodologi Penafsiran Realis ala Hassan Hanafi", dalam Jurnal al-Qur'an dan Hadits, Vol. 1, No. 1 (Yogyakarta: Fakultas Ushuluddin IAIN Sunan Kalijaga, 2000), h. 16-18.

${ }^{2}$ Abdul Mustaqim, Epistemologi Tafsir Kontemporer (Yogyakarta: LKiS, 2010), 72; bandingkan Abd. A'la, Dari Neo Modernisme ke Islam Liberal (Jakarta: Dian Rahmat, 2009), h. 85.

${ }^{3}$ Mustaqim, Epistemologi Tafsir, 75; Robert D. Lee, Mencari Islam Autentik: Dari Nalar Puitis Iqbal hingga Nalar Kritis Arkoun, terj. Ahmad Baiquni (Bandung: Mizan, 2000), h. 195.

${ }^{4}$ Lihat Nasr Hâmid Abû Zayd, Ishkâlîyât al-Qirâah wa Âlîyât al-Ta'wîl (Beirut: Markaz alThaqâfi, 1994), h.-48.

${ }^{5}$ Pendekatan tersebut berusaha mendeskripsikan suatu bahasa berdasarkan sifat yang khas yang dimiliki oleh bahasa. Hal ini dilakukan dengan melibatkan telaah sinkronik-diakronik, menggunakan analisis hubungan sintagmatik dan paradigmatik. Lihat Mustaqim, Epistemologi Tafsir, h. 77. 
kan Jamâl al-Bannâ dianggap sebagai rujukan ideal dalam rangka memperoleh penafsiran yang memihak kepada keadilan dan kemaslahatan manusia.

\section{Sketsa Biografis Jamâl al-Bannâ}

Ahmad Jamâl al-Dîn Ahmad 'Abd al-Rahmân atau yang akrab dipanggil Jamâl alBannâ merupakan adik bungsu dari Hasan al-Bannâ (1906-1949 M), pendiri kelompok al-Ikhwân al-Muslimûn. Ia lahir pada bulan Desember 1920 di sebuah desa yang masih asri dan cukup terkenal di Propinsi Bukhayrah, yakni Desa Mahmûdîyah, sekitar 50 kilometer dari kota wisata Alexandaria-Mesir ${ }^{6}$ dan meninggal pada 30 Januari 2013 dalam usia lebih dari 93 tahun.

Ayahnya bernama Ahmad b. 'Abd al-Rahmân b. Muhammad al-Bannâ al-Sâ'atîn atau yang biasa dipanggil Shaykh al-Bannâ. Sedangkan ibuntya bernama Umu Sa'ad Saqar.8 Orang tuanya memberi nama Jamâl agar kelak menjadi sosok revolusioner besar seperti Jamâl al-Dîn al-Afghânî. Berbeda dengan kakaknya yang menjadi aktivis, juru dakwah, dan terhitung pembaru Islam (mujaddid) abad $20 \mathrm{M}$, sang adik bungsu justru dikenal luas dengan reputasinya sebagai seorang pemikir dan penulis liberal. Jamâl al-Bannâ dikenal cukup berani menggugat ajaran-ajaran pokok yang telah baku dalam sharî‘at Islam.

Jamâl al-Bannâ adalah seorang tokoh yang secara intelektual dididik dan dibesarkan dalam tradisi keislaman kuat. ${ }^{9}$ Pada prosesnya, sense of crisis-nya sanggup mengantarkannya untuk mendeklarasikan sebuah mazhab baru yang ia beri nama dengan Revivalisme Islam (al-Ihyâ' al-Islâmî atau Islamic Revivalism). Di antara isu yang diangkat dalam ide pembaruannya adalah pentingnya merekonstruksi metode penafsiran al-Qur'an.

Di sini Jamâl mencoba menegaskan bahwa untuk menjadi rasional dan progresif, umat Islam bisa menggali rasioanalitas dari sumber utamanya, al-Qur'an. Seperti ini pula yang ditegaskan oleh Hâshim Sâlih—spesialis penerjemah karya-karya Muhammad Arkûn dari bahasa Prancis ke dalambahrasa Arab_dalam surat kabar al-Sharqal-Awsat yang menulis artikel dengan judul "Jamâl al-Bannâ bayn al-Islâh al-Dînî wa al-Tanwîr" (Jamâl al-Bannâ antara reformasi keagamaan dan pencerahañ), đi mana dalam artikel tersebut

${ }^{6}$ http://ar.wikipedia.org/wiki/Jamâl_al_Banna.

${ }^{7}$ Ia adalah pengarang kitab al-Fath al-Rayyân fî Tartîb al-Musnad al-Imâm Ahmad b. Hanbal al-Shaybânî sebanyak 24 jilid. Lihat Muhammad 'Ajjâj al-Khâtib. Usûl al-Hadîth: Ulûmuh wa Mustalahuh (Beirut: Dâr al-Fikr, 1997), h.329. Lihat juga Ashraf 'Abd-al-Qâdir, "Jamâl al-Bannâ: al-Almânîyah laysat diddu al-Dîn wa lâkin diddu an Yadkhula al-Dîn fî al-Siyâsah" (wawancara) dalam www.ahewar.org/debat/14-02-2003/diakses 09-05-2007.

${ }^{8}$ Lihat Ensiklopedi tokoh yang memuat profil ibunda Hasan al-Bannâ dalam www.egyptwindow. net/nafidatumasr/07-08-2007.

${ }^{9}$ Walaupun begitu, sistem pendidikan yang diterapkan oleh Ayahnya, Ahmad al-Bannâ, yang juga pengarang al-Fath al-Rayyân fî Tartîb al-Musnad al-Imâm Ahmad b. Hanbal al-Shaybânî, sangat pluralistik. Lihat al-Qâdir, "Jamâl al-Bannâ: al-'Almânîyah". - 
ia memandang Jamâl al-Bannâ sebagai pemikir yang setelah melalui proses mendekonstruksi ideologi yang bersemayam dalam khazanah turâts Islam kemudian digalilah prinsipprinsip rasionalitas yang bersumber dalam sumber utamanya, al-Qur'an. Oleh karenanya, Sâlih kemudian menjulukinya dengan Martin Luther-nya Islam karena kedua tokoh, baik Euther maupun Jamâl, sama-sama menggerakkan reformasi keagamaan (al-islâh aldînî) dalam agamanya masing-masing. ${ }^{10}$

Jamâl al-Bannâ merupakan pemikir prolifik yang karyanya mencapai ratusan buku. Ada beberapa karyanya yang khusus mengupas tentang metodologi penafsiran al-Qur'an. Karya-karya tersebut antara lain: Al-Aslân al-Azîmân: al-Kitâb wa al-Sunnah (Ru'yah Jadîdah) (1982); Al-Awdah ilâ al-Qur'an (1984); At-Hukm bi al-Qur'an wa Qadiyyat Tatbîq al-Sharî́ah (1986); Nahw Fiqh Jadîd: Muntaliqât wa Mafâhim, Fahm al-Khitâb al-Qur'anî (1995); Tathwîral-Qur'art(2001); Tafsîr al-Qur'an al-Karîm bayn al-Quddâmâ waat-Muhaddithîn (2003); Tafnîd Da'wâ Hadd al-Naskh fî al-Qur'an al-Karîm (2004), Tajdîd al-Æslâm wa I'âdat Ta'sîs Manzûmatal-Ma'rifah al-Islâmîyah (2005), dan lain-lain.

\section{Penafsiran al-Qur'an Menurut Jamâl al-Bannâ}

\section{Al-Qur'an sebagai Kitab Mukjizat}

Al-Qur'an merupakan mukjizat Islam dan menjadi media untuk mendapatkan hidayah. Menurut Jamâl, hal ini harus dipahami sebagai kunci dalam memahami eksistensi alQur'an. Selama al-Qur'an menjadi pegangan umat Islam, sudah semestinya ia memenuhi standar maupun unsur mukjizat: sebuah 'kekuatan' khusus yang akan memberikan kebenaran al-Qur'an sebagai esensi keimanan di setiap masa. Ini berarti setiap masa, bahkan tempat sekalipun, mempunyai hak yang sama untuk tidak memonopoli keistimewaan al-Qur'an dalam memberikan petunjuk. ${ }^{11}$

Setiap model dakwah dalam Islam selalu mengusung spirit bahwa al-Qur'an merupakan sumber utama, seperti slogan yang diungkapkan oleh gerakan al-Ikhwân al-Muslimûn, "al-Qur'an dustûrunâ" (al-Qur'an adalah undang-undang kita). Demikian halnya dengan pembaruan Jamâl al-Bannâ yang menempatkan al-Qur'an sebagai kerangka utamanya. Perbedaan keduanya adalah jika model yang pertama memahami al-Qur'an melalui kitabkitab tafsîr klasik seperti tafsîr al-Tabarî, al-Qurtubî, Ibn Katsîr, al-Râzî, dan lain-lain), maka pembaruan Jamâl al-Bannâjustru mengasi seluruh produk tafsir klasik, karena

${ }^{10}$ Hâshim Sâlih juga menempatkan proyek pemikiran Jamâl al-Bannâ setara dengan proyek para pemikir Islam-kontemporer yang lain, seperti Muhammad al-Thalabî, 'Abd. al-Majîd alSharafî, Hasan Hanafî, Muhammad Arkûn, Muhammad 'Âbid al-Jâbirî, 'Abd. al-Karîm Shoroush dan lain łain. Lihat HâshimtSâlih, "Jamâl al-Bannâ... Bayn al-Islâh al-Dînî wa al-Tanwîr" dalam www.assyarqalawsat.com/24-Mei-2004.

${ }^{11}$ Jamâl al-Bannâ, al-Islâm kamâ Tuqaddimuhu Da'wat al-Ihyâ' al-Islamî (Kairo: Dâr alFikr al-Islâmî, 2004), h. 59. 
baginya setiap tafsir merupakan produk masanya. ${ }^{12}$ Bagi Jamâl, produk tafsir klasik tersebut banyak dicemari oleh riwayat hadîth-hadîth mawdî́, konservatisme sebagai worldview, maupun penyusupan cerita-cerita Isrâ̂tthyat. Di samping itu, konstruksi intelektual setiap mufassir banyak berkontribusi dalam memproduksi penafsiran. Dengan begitu, al-Zamakhsharî yang berpaham Muktazilah-Linguistis (mu'tazilîyan lughawîyan) memberikan tafsîrnya atas ideologi Muktazilahnya, sama halnya dengan penafsir lain seperti Ibn Kathîr dan al-Tabarî yang memberikan kontribusi tafsîrnya atas dasar periwayatan, penggunaan datil-dalil naqli, dan lain-lain. ${ }^{13}$

Dalam memahami al-Qur'an sebagai kitab mukjizat, Jamâl al-Bannâ tidak berpijak pada penafsiran klasik. Karena menurutnya, khazanah tafsîr tersebut menjadi penghalang bagi kaum Muslim dalam memahami makna yang dikehendaki al-Qur'an. Dalam bukunya, Mâ ba'd al-Ikhwân al-Muslimîn, Jamâl al-Bannâ menyampaikan beberapa kritik terhadap tafsîr al-Qur'an:

Pertama, semua tafsîr hanya dijadikan justifikasi terhadap wahyu Tuhan, baik secara riwayat maupun maknawi, dari yang lebih rendah ke yang lebih tinggi, dari yang bersifat mungkin kepada yang bersifat meyakinkan.

Kedua, satu-satunya penafsiran al-Qur'an yang tidak mungkin salah adalah tafsîr al-Qur'an itu sendiri, yakni ayat al-Qur'an yang menafsirkan ayat yang lain. ${ }^{14}$ Dengan kata lain, satu ayat mungkin tidak secara rinci menjelaskan tentang sebuah permasalahan, kemudian ada ayat lain yang menjelaskannya. Penafsiran suatu ayat harus sesuai dengan konteksnya, dan semua itu terdapat dalam diri al-Qur'an sendiri. Ia tidak membutuhkan "tafsîr luar". ${ }^{15}$

Ketiga, pada dasarnya al-Qur'an diturunkan sebagai petunjuk kepada manusia. Inilah yang telah dilakukan al-Qur'an dengan caranya sendiri (pendekatan seni dan psikis). Setelah itu, al-Qur'an mengalirkan nilai-nilai universalnya. Dalam konteks ini, al-Qur'an tidak jauh berbeda dengan mukjizat-mukjizat yang lain. Dia seperti matahari yang bersinar, lautan yang bergelombang, dan bulan yang terang. Hingga al-Qur'an mampu memengaruhi jiwa seseorang.

Al-Qur'an berhasil menciptakan jiwa-jiwa yang beriman di masa Nabi. Pada masa itu, tidak ada tafsîr maupun penjelasan. Namun demikian, para sahabat mampu menciptakan iklim yang progresif serta peradaban yang luhur dan meninggal dunia tanpa melakukan seperti yang dilakukan oleh para mufassir. ${ }^{16}$

\footnotetext{
${ }^{12}$ Jamâl al-Bannâ, Mâ Ba'd al-Ikhwân al-Muslimîn (Kairo: Dâr al-Fikr al-Islâmî, 1996), h. 129.

${ }^{13}$ Ibid., h. 126.

${ }^{14}$ Jamâl al-Bannâ, Hâ Huwa Dhâ al-Barnâmij al-Islâmî (Kairo: Dâr al-Fikr al-Islâmi, 1991),
} h. 17.

${ }^{15}$ Jamâl al-Bannâ, Tajdîd al-Islâm wa I'âdat Ta'sîs Manzûmat al-Ma'rifah al-Islâmîyah (Kairo: Dâr al-Fikr al-Islâmî, 2005), h. 228.

${ }^{16}$ al-Bannâ, Mâ ba'd, h. 127-128. 
MIQOT Vol. XXXVIII No. 2 Juli-Desember 2014

\section{Tiga Tahapan dalam Memahami al-Qur'an}

Dalam rekonstruksi penafsiran al-Qur'an, Jamâl al-Bannâ mengajukan model yang berbeda dengan pemikir lainnya. Ia mengetengahkan tahapan-tahapan yang harus dilalui oleh setiap penafsir dalam memahami al-Qur'an. Trilogi pendekatan itulah yang dapat menghantarkan penafsir untuk sampai pada makna hakiki al-Qur'an. Di antara tiga pendekatan itu antara lain: pendekatan seni, pendekatan psikis, dan pendekatan rasional.

Sebagian ulama berpendapat bahwa agama — terutama Islam—-bertentangan dengan seni. Namun, bagi Jamâl, seni adalah sarana interaksi dengan hati dan yang berkaitan dengannya, seperti perasaan, cinta, dan keadilan. Seni membuka diri dengan kebaikan dan menjauhi keburukan. Seni juga dapat membedakan antara kebaikan dari sebuah perbuatan baik. Begitu juga sebaliknya. Inilah yang menjadi poros agama-agama. ${ }^{17}$

Apabila seni adalah pintu masuk menuju segala kebaikan, sementara poros agama juga di sana, maka jelaslah bahwa di antara agama dan seni terjalin hubungan yang erat. Bagi Jamâl, seni adalah pintu masuk dan sebuah alat dalam agama. Dengan demikian, seni juga bisa hadir dalam ritual agama.

Pertentangan yang muncul disebabkan asumsi yang melihat seni sebagai sesuatu yang lahir dari hawa nafsu dan dilakukan untuk kepentingan seni semata. Sementara seni yang digunakan al-Qur'an adalah seni untuk mereformasi dan memperbaiki keadaan manusia. Untuk merealisasikan hal itu, seni tentu tidak bisa dilepaskan, karena tidak mungkin memperbaiki jiwa dan hati seseorang tanpa melalui jalur seni. ${ }^{18}$ Bahkan, panca indra pun bisa tunduk olehnya. Seperti yang tertuang dalam Q.S. al-Zumar: $23^{19}$ :

"Gemetar karenanya kulit orang-orang yang takut kepada Tuhannya, kemudian menjadi tenang kulit dan hati mereka di waktu mengingat Allah. Itulah petunjuk Allah, dengan kitab itu Dia menunjuki siapa yang dikehendaki-Nya. Dan barangsiapa yang disesatkan Allah, niscaya tidak ada baginya seorang pemimpin pun."

Rasulullah juga menyatakan bahwa hati dapat memperbaiki (dan merusak) jiwa seseorang.

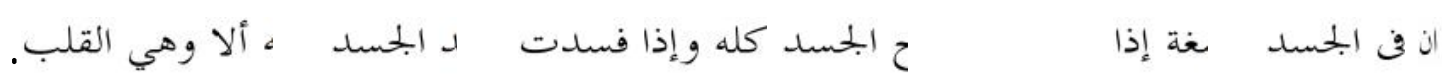

"Sesungguhnya dalam jiwa seseorang terdapat segumpal daging. Bila daging itu baik, seluruh jiwa akan baik. Bila tidak, seluruh jiwa akan rusak. Itulah hati."20

${ }^{17}$ Jamâl Al-Bannâ, Nahw Fiqh Jadîd: Muntaliqât wa Mafâhîm: Fahm al-Khitâb al-Qur'ânî, Vol. 1 (Kairo: Dâr al-Fikr al-Islâmî, 1996), h. 154.

${ }^{18}$ Ibid.

${ }^{19}$ Jamâl al-Bannâ, al-Awdah ilâ al-Qur'ân (Kairo: Dâr al-Shurûq, 2008), h. 48.

${ }^{20}$ al-Bannâ, Nahw, Vol. 1, h. 154. 
Dari sini, Jamâl menegaskan bahwa pemahaman kaum salaf yang keliru terhadap al-Qur'an adalah pemikiran bahwa al-Qur'an merupakan kitab sastra, sehingga penafsiran yang dihasilkan berkutat kepada al-i'jâz al-bayânî. Baginya, al-Qur'an adalah kitab seni terbesar dan kemukjizatan terbesarnya adalah penggunaan bahasa sebagai alat untuk memahami seni yang terdapat dalam al-Qur'an. Rahasia kemukjizatan (pembacaan) musikal yang dimunculkan dari al-Qur'an bisa menjadi pendekatan psikologis, hanya dengan mendengar bacaan al-Qur'an. Ini adalah karakteristik seni. Hanya dengan mendengarkan seseorang bisa tercuci otaknya, seperti penikmat musik di Barat yang tercuci otaknya ketika mendengarkan Beethoven atau opera-opera musikal. Hal ini juga ditegaskan dalam al-Qur'an surah al-Hasyr/59: 21:21

"Kalau sekiranya Kami turunkan al-Qur'an ini kepada sebuah gunung, pasti kamu akan melihatnya tunduk terpecah belah disebabkan ketakutannya kepada Allah. Dan perumpamaan-perumpamaan itu Kami buat untuk manusia supaya mereka berpikir."22

Untuk membumikan nilai seninya, al-Qur'an menggunakan pendekatan baru dalam pengungkapan. Sebuah cara yang tidak terkenal sebelumnya. Dalam tradisi Arab, hanya ada pengungkapan nathr (prosa) yang kekuatannya terletak pada keserasian makna dan konteks, atau syair yang kekuatannya terletak di penyeragaman kata akhir.

Al-Qur'an datang dengan pendekatan baru. Dia bukan nathr karena di setiap akhir kata terdapat "kunci", bukan juga syair karena dia tidak mengikuti jalur syair seperti wazn (aturan dalam syair arab) dan keseragaman kata akhir (qawâfi). Pendekatan yang diusung al-Qur'an tidak pernah terbayangkan oleh orang-orang Arab sebelumnya. Tidak seorang pun bisa meniru gaya bahasa dan penyampaian al-Qur'an. Oleh karenanya, benar bila dikatakan bahwa bahasa Arab adalah nathr, syair, dan al-Qur'an (inna al-lughah alArabîyah nathr, wa shi'r, wa Qur'an). ${ }^{23}$ Gaya penyampaian al-Qur'an ini berpengaruh besar terhadap orang-orang yang menggunakan bahasa Arab, dan pada akhirnya menjadi bagian tidak terpisahkan dari susunan kalimat bahasa Arab. ${ }^{24}$

Dalam konteks seni, hal pertama yang dapat dipahami manusia adalah struktur musik, sebab al-Qur'an harus disuarakan melalui pembacaan. Maka, membaca al-Qur'an yang baik membutuhkan pendengaran dan talaqqî (membaca di hadapan guru). Dalam al-Qur'an, terdapat kalimat-kalimat yang membutuhkan cara khusus dalam membacanya. Contohnya, dalam surah al-Fajr "alam tara kayf facal rabbuk bi 'Âd" (Apakah kamu [Muhammad] tidak mengetahui apa yang dilakukan Tuhanmu terhadap kaum 'Âd). Kalimat “alif-lâm-

${ }^{21}$ Jamâl al-Bannâ, Istrâtîjîyah al-Da'wah al-Islâmîyah fí Qarn 21 (Kairo: Dâr al-Fikr alIslâmî, 2000), 59.

${ }^{22}$ Lihat juga Q.S. al-Isrâ'/17: 107-108.

23Jamâl al-Bannâ, al-Aslân al-Azîmân "Al-Qur'ân wa al-Sunnah"; Ru'yah Jadîdah (Kairo: Matba'ah Hisân, 1982), h. 20.

${ }^{24}$ al-Bannâ, Nahw, Vol. 1, h. 156-157. 
mîm" dalam ayat ini dibaca "alam". Padahal dalam ayat lain dengan tulisan yang sama dibaca "alif-lâm-mîm" seperti yang terdapat dalam awal surah al-Baqarah.

Oleh karena itu, menurut Jamâl, al-Qur'an pertama kali semestinya dibacakan kepada ahli al-Qur'an untuk memperbaiki dan membenarkan bacaannya. Berbeda dengan kitab-kitab yang lain, membaca al-Qur'an yang baik membutuhkan nada tinggi, rendah, panjang, pendek, dengung, dan seterusnya, yang terlebih dahulu harus diketahui pembaca al-Qur'an. Membacakannya kepada mereka yang ahli akan menghindarkan seseorang dari kesalahan membaca. ${ }^{25}$

Terlepas dari itu semua, membaca al-Qur'an dengan cara yang keras dapat menghadirkan ketenangan tersendiri. Struktur seninya terdengar indah. Seseorang yang beriman dan berinteraksi dengan al-Qur'an, seperti seniman berinteraksi dengan nada musik atau petikan lagu. Walaupun terdapat perbedaan yang sangat besar antar-keduanya.

Al-Qur'an mempunyai struktur musik tersendiri. Tajwîd pada titik tertentu dapat mengungkap musik al-Qur'an, karena ia adalah ilmu dan penadaan musik al-Qur'an yang bisa memperindah bacaan dan hiasan membaca, meski tanpa bantuan alat musik tertentu. Maka, ketika suara tertata sesuai dengan kaidah musik, dia dapat meninggalkan kesan cukup mendalam dalam jiwa. ${ }^{26}$ Bahkan, tidak berlebihan jika dikatakan bahwa tidak satu kitab pun yang menggunakan pengaruh musik seperti al-Qur'an. Al-Qur'an memberikan kreasi musik tersendiri kepada kita. Komposisi huruf dan kata dalam al-Qur'an seakan menjadi bel pelantun musik walaupun tanpa gitar, nada, bahkan suara.

Itulah cara-cara memperindah suara dalam bahasa dan mempunyai dampak psikologis. Kelebihan mukjizat al-Qur'an dalam suara ini dapat mempengaruhi, baik bagi orang yang memahami artinya atau tidak. Oleh karenanya, dengan mendengarkan al-Qur'an, terlepas paham atau tidak, seseorang telah tertarik. ${ }^{27}$

Menurut Jamâl, berbeda dengan musik bergitar lainnya, musik al-Qur'an pada dasarnya adalah musik bahasa yang diatur oleh tata bahasa itu sendiri. Itulah "lagu yang indah". ${ }^{28}$ Itulah perbedaan mendasar antara tajwîd dan nada. Tajwîd diatur oleh kaidah, sedangkan nada lebih bebas sesuai dengan psikologi dan pemahaman yang bersangkutan. Oleh karenanya, penadaan seseorang terhadap teks akan berbeda dengan yang lain. Nada bebas tidak bisa diterapkan dalam al-Qur'an.

Dalam konteks musik al-Qur'an, menurut Jamâl, sebenarnya al-Qur'an tidak memberikan "ruang lebih" bagi para ahli nada dan musik, karena setiap ayat dalam al-Qur'an membawa musiknya sendiri. Karena pengaruh musik ini, telinga kemudian menerima,

\footnotetext{
${ }^{25}$ al-Bannâ, al-Aslân, h. 15.

${ }^{26}$ Ibid., h. 16-17.

${ }^{27}$ al-Bannâ, al-Awdah, h. 50.

${ }^{28}$ al-Banna, Nahw, Vol. 1, h. 162.
} 
bahkan tertarik untuk terus mendengarkannya. ${ }^{29}$ Dari sini kemudian tercipta pengaruh keimanan..$^{30}$ Tujuan sebenarnya dari musik al-Qur'an bukanlah keindahan itu sendiri, tapi penyatuan makna dengan emosi. Oleh karenanya, bagusnya suara-walaupun itu penting_-bukan segala-galanya. Yang lebih penting adalah penyatuan suara dan makna.

Deskripsi seni di sini tidak hanya menjadi salah satu cara al-Qur'an mempengaruhi jiwa, akan tetapi menjadi sarana satu-satunya untuk bisa memahami Allah dan hal gaib lainnya. Bahkan deskripsi seni ini dapat digunakan untuk menerangkan hal yang tampak, tapi tidak bisa diterangkan secara ilmiah dan pasti. ${ }^{31}$ Ketika al-Qur'an diharapkan menjadi petunjuk bagi manusia, menurut Jamâl, tidak mengejutkan bila deskripsi seni dijadikan salah satu jalannya—untuk tidak mengatakan jalan satu-satunya—untuk bisa mewujudkan semua itu. Semua tentang Allah dan hal gaib lainnya adalah sasaran dari pendekatan ini. ${ }^{32}$

Disamping itu, karena tujuan al-Qur'an adalah memperbaiki manusia, maka memperbaiki tersebut harus melalui pendekatan psikis dan nurani sebagai penyempurna dari pendekatan awal melalui jalur musik dan seni. Substansi dua pendekatan di atas mengarah kepada jiwa. ${ }^{33}$

Yang perlu ditegaskan adalah, al-Qur'an tidak berhenti sampai di sini (pendekatan rasa). Ia juga menggunakan pendekatan rasional yang mungkin tidak pernah dilakukan oleh kitab-kitab lain. Contoh-contoh yang telah disampaikan adalah buktinya. Al-Qur'an menggunakan sesuatu yang fitrah dan rasional.

Al-Qur'an menggunakan pendekatan rasa untuk mempersiapkan jiwa hingga bisa menerima tujuan al-Qur'an, yang dapat diringkas dalam dua hal: Pertama, penggunaan akal dan mengimani nilai-nilai universal. Tidak ditemukan satu kitab pun, seperti al-Qur'an, yang mendorong pembacanya untuk berkeliling dunia guna mengetahui dan mempelajari peninggalan orang-orang terdahulu. ${ }^{34}$ Dengan begitu, mereka dapat mengetahui keagungan Allah dan menemukan hikmah-hikmah tersimpan. Al-Qur'an menganjurkan agar manusia menggunakan akal pikirannya. Untuk mendukung argumentasinya, Jamâl banyak mengutip potongan-potongan ayat al-Qur'an seperti Q.S. al-Baqarah/2: 73 dan 242, la'allakum ta'qilûn (agar supaya engkau berpikir), Q.S. al-Baqarah/2: 219, la'allakum tatafakkarûn (agar supaya engkau berpikir), Q.S. al-An'âm/6: 50, afalâ tatafakkarûn (apakah engkau

${ }^{29}$ Proses transferensi dari suara yang diterima oleh telinga mampu menjadi alat memperlancar proses hidayah. Menurut Jamâl, hal ini seperti yang tergambar dalam Q.S. al-Jin/72: 1 dan 13; Q.S. al-Mâidah/5: 83. Lihat al-Bannâ, al-Awdah, h. 48-49.

${ }^{30}$ al-Banna, al-Aslân, h. 22.

${ }^{31}$ al-Bannâ, Nahw, Vol. I, h. 172.

${ }^{32}$ Q.S. al-Nûr/24: 35-41. Lihat al-Bannâ, al-Islâm Kamâ, h. 66.

${ }^{33}$ Adapun contoh pendekatan psikis bisa ditelusuri Q.S. al-Mu'minûn/23: 37-38 dan 90; Q.S. Saba'/34: 3; Q.S. al-Taghâbun/64: 7; Q.S. Qâf/50: 39-40; Q.S. al-Baqarah/2: 204-205; Q.S. Ali Imrân/3: 75; Q.S. al-Qiyâmah/75: 33; Q.S. al-Thûr/52]: 35; Q.S. al-Anbiyâ'/21: 23; dan Q.S. Yûnus/10: 79.

34al-Bannâ, al-Islâm kamâ, h. 67. 
tidak berpikir), dan lain sebagainya. ${ }^{35}$ Dalam ayat lain, Allah juga menjelaskan penyebutan orang-orang yang berakal dengan ûlû al-albâb. Hal ini seperti yang tertuang dalam Q.S. al-Baqarah/2: 179 dan 269, Q.S. Âli Imrân/3: 7.36

Adapun sasaran kedua dari tujuan al-Qur'an adalah beriman kepada nilai-nilai universal, seperti kebaikan, cinta-kasih, kebebasan, keadilan, kebenaran, kehormatan, dan semua hal yang menjauhkan seorang Muslim dari kejelekan, kezaliman, egoisme, dan mengikuti hawa nafsu. ${ }^{37}$

Rasionalisasi al-Qur'an, sebagai tahapan terakhir yang hendak dibangun Jamâl al-Bannâ, sebenarnya tidak membatasi kepada sebuah metode tertentu dalam 'membaca' al-Qur'an. Karena baginya, al-Qur'an sebagai media revolusi peradaban manusia yang berkeimanan tidak akan membatasi satu metode tertentu untuk menafsirkan al-Qur'an. Namun, Jamâl menolak jika satu metode tertentu mempunyai garansi sebagai satu-satunya cara menemukan kebenaran. Apa saja boleh dan siapapun boleh/otonom untuk menafsirkan selama hal itu secara aksiologis diorientasikan untuk memupuk kesadaran imaniah seseorang. Hal ini jugalah yang mendasari Jamâl al-Bannâ untuk menempatkan hikmah sebagai sumber ketiga Islam karena sifatnya yang fleksibel dalam membangun pola pikir yang otonom, humanis, dan berbasis kemaslahatan manusia. Bahwa penafsir harus menguasai ilmu-ilmu kekinian, setidaknya berbagai teori-teori, ilmu sejarah, ilmu sosiologi, ilmu ekonomi, maupun ilmu politik menjadi kerangka referensial mutlak bagi seorang penafsir dalam membaca teks al-Qur'an. ${ }^{38}$

Semua itu menunjukkan adanya optimalisasi akal dan iman dalam nilai-nilai universal. Apalagi, semua itu melalui pendekatan musik dan seni. Al-Qur'an mempersiapkan jiwa untuk bisa menerimanya, dapat membumikan yang menjadi cita-cita Islam. Berakal dan beriman akan membuat seseorang bisa menerima dengan tulus, tidak tersesat oleh khurafât dan tidak dikalahkan oleh syahwat. Lebih jauh, nilai-nilai itu dapat tercerminkan dalam kehidupan masyarakat.

\section{Akar Teoretis Penafsiran Jamâl al-Bannâ: dari Kritik Ideologi hingga Anarkisme Metode}

Dalam pandangan penulis, lontaran kritik yang diajukan Jamâl al-Bannâ terhadap setiap produk pemikiran Islam, seperti tafsir di atas, adalah usaha menolak sistem pengetahuan Islam klasik yang dianggapnya sebagai ideologi. ${ }^{39}$ Ideologi—yang bermula dari konsep

${ }^{35}$ al-Bannâ, al-Awdah, h. 54-55.

${ }^{36}$ Ibid., h. 55.

${ }^{37}$ al-Bannâ, al-Islâm kamâ, h. 67.

${ }^{38}$ al-Bannâ, al-Awdah, h. 94.

${ }^{39}$ Pada prinsipnya terdapat tiga arti utama dari kata ideologi, yaitu (1) ideologi sebagai kesadaran palsu; (2) ideologi dalam arti netral; dan (3) ideologi dalam arti keyakinan yang 
idola Francis Bacon (1561-1626) ${ }^{40}$ — secara sistemik hanya akan melahirkan konservatisme dan ketidaksadaran betapa kekuasaan-kekuasaan klasik sangat menghegemoni pemikiran Islam saat ini. Di sini terlihat kesamaan visi antara apa yang diungkapkan Jamâl al-Bannâ dengan kritik ideologi ala Jürgen Habermas yang terakomodasi dalam "Teori Kritis"41. Teori tersebut dikonstruksi oleh Habermas melalui dua cara, yakni melontarkan kritik terhadap saintisme atau positivisme sebagai ideologi pengetahuan modern ${ }^{42}$ dan menunjukkan bagaimana positivisme-yang berhenti pada tatanan fakta-fakta objektif - telah menghasilkan masyarakat yang irasional dan ideologis. Menurut tradisi teori kritis, suatu pengetahuan yang terungkap dalam teori senantiasa terkait dengan praksis-sosial, dan dengan pemisahan teori atau pengetahuan dengan praksis-sosial justru membuat teori itu menjadi ideologis. Dengan kata lain, teori kritis merupakan sebuah teori dengan maksud praktis. ${ }^{43}$ Caranya adalah melalui analisis hermeneutik sebagai cara untuk menemukan dan memahami makna suatu teks, karya seni, serta produk kebudayaan lainnya. Hal tersebut disebabkan produk dan aktivitas kebudayaan sebagai objek tidak terpisah dari subjek yang melahirkan atau yang menciptakan. Ini berarti teori kritis berusaha untuk dapat menembus realitas sosial sebagai fakta sosiologis guna menemukan kondisi kondisi yang bersifat transendental yang melampaui data empiris.

Senada dengan Habermas yang menolak dimensi positivisme yang terlalu mendewakan saintisme, Jamâl al-Bannâ juga menolak gagasan penafsiran yang dilakukan baik oleh

tidak ilmiah. Lebih jauh lihat Franz Magnis-Suseno, Filsafat Sebagai Ilmu Kritis (Yogyakarta: Kanisius, 1992), h. 230; Karl Mannheim, Ideologi dan Utopia: Menyingkap Kaitan Pikiran dan Tindakan, terj. F. Budi Hardiman (Yogyakarta: Kanisius, 1998), h. xvii.

${ }^{40} \mathrm{Di}$ sini, Francis Bacon mengelompokkan idola sebagai hal-hal irasional itu menjadi empat golongan: 1) idola terhadap suku bangsa (awhâm al-jins aw awhâm al-qabîlah), yaitu kecenderungan untuk menerima begitu saja berbagai proposisi dengan alasan mempertahankan nilai adat dan kepercayaan mitis; 2) idola terhadap goa (awhâm al-kahfi), yaitu kecenderungan untuk menerima realitas begitu saja dan tidak bisa bersikap kritis; 3) idola terhadap pasar (awhâm al-sûq), yaitu kecenderungan untuk terpengaruh kepada opini publik (gosip) yang pada masa Bacon biasa diajukan di pasar; 4) idola terhadap teater (awhâm al-masrah), yaitu kecenderungan untuk menerima begitu saja teori-teori dan dogma-dogma tradisional. đdola dalam pengertian Bacon bernilai negatif, semacam pengetahuan palsu yang sering menyesatkan. Lihat Yûsuf Karam, Târîkh al-Falsafah al-Hadîthah (Kairo: Dâr al-Ma'ârif, 1986), h. 47-48; Mahmûd Hamdî Zaqzûq, Dirâsât fî al-Falsafah el-Hadîthah (Kairo: Dâr al-Fikr al-'Arabî, 1993), h. 42-43.-

${ }^{41}$ Melalui teori kritts ini, Jürgen Habermas membedakan tiga macam ilmu pengetahuan yaitu: Pertama, Ilmu-ilmu empiris-analitis. Yang dimaksud adalah kelompok ilmu-ilmu alam. Kedua, Ilmu-ilmu historis-hermeneutis. Di sini termasuk ilmu sejarah, dan sebagainya. Ketiga, Ilmu-ilmu kritis-refleksif. Yang termasuk dalam kelompok ini adalah filsafat, kritik ideologi, dan psikoanalisis. Lingkungannya adalah kekuasaan. Dikutip dari Franz Magnis-Suseno, PijarPijar Filsafat: Dari Gatholoco ke Filsafat Perempuan, dari Adam Muller ke Postmodernisme (Yogyakarta: Kanisius, 2005), h. 157.

${ }^{42}$ Lebih jauh, lihat ulasan dalam Ben Agger, Teori Sosial Kritis (Yogyakarta: Kreasi Wacana, 2003), 16; F. Budi Hardiman, Melampaui Positivisme dan Modernitas: Diskursus Filosofis tentang Metode Ilmiah dan Problem Modernitas (Yogyakarta: Kanisius, 2003), h. 160-163.

${ }^{43}$ F. Budi Hardiman, Kritik Ideologi: Pertautan Pengetahuan dan Kepentingan (Yogyakarta: Kanisius, 1990), h. 54-59. 
Nasr Hâmid Abû Zayd atau Muhammad Shahrûr yang "terlalu" mengilmiahkan al-Qur'an atau membatasi penafsiran terhadap metode tertentu. ${ }^{44}$ Bagi Jamâl, semangat pengetahuan modern sebagai basis penafsiran hanya akan menahbiskan manusia sebagai objek penafsiran semata yang justru mengeliminir eksitensi manusia sebagai muara teks-teks keagamaan. Meminjam istilah Habermas di atas, benih-benih modernisme sebagai ciri khas pemikiran positivistik telah menghasilkan masyarakat yang irasional dan ideologis.

Cara analisis hermeneutis seperti yang diusung oleh Habermas tidak lantas menjadi cara kerja Jamâl al-Bannâ dalam menafsirkan sebuah teks. Secara kategoris, kerangka berpikir Jamâl al-Bannâ menolak dua klan pemikiran (salafisme dan westernisme). Dalam tafsîr al-Qur'an, misalnya, jika kacamata insider menjadi dalih menolak khazanah intelektual outsider (Barat) karena merasa cukup dengan khazanah metode tafsîr klasik, ini tentu berbeda dengan pemikir Islam yang menggunakan perspektif outsider seperti hermeneutik sebagai alternatif metode, untuk tidak mengatakan satu-satunya metode, dalam menafsirkan al-Qur'an karena dianggap paling mampu menjangkau problematika penafsiran.

Bagi pendukung hermeneutika, pada prinsipnya metode ini merupakan suatu ilmu atau teori metodis tentang penafsiran yang bertujuan menjelaskan teks mulai dari ciricirinya, baik secara objektif (arti gramatikal kata-kata dan bermacam variasi historisnya) maupun subjektif (maksud pengarang). Teks-teks yang dihampiri terutama berkenaan dengan teks-teks otoritatif (authoritative writings), yakni teks-teks kitab suci (sacred scripture). Pemaknaan hermeneutik sedemikian sebanding-maksud dengan tafsîr dalam khazanah Islam. ${ }^{45}$

Memaksakan hermeneutik sebagai ikon utama tafsîr boleh jadi mengusik kemapanan dinamika pemikiran keislaman, tidak hanya dalam disiplin ilmu-ilmu al-Qur'an tapi juga ilmu-ilmu Hadîts. Karena apa yang dicanangkan oleh metode ini pada dasarnya ingin mengkritisi sakralitas teks. Bahkan, trend sakralisasi itu juga melebar pada produk pemikiran keagamaan yang jelas-jelas sekadar pemahaman atas ajaran dan bukan Islam itu sendiri. Alhasil, kerangka tafsîr yang ditawarkan hermeneutik boleh jadi akan menghentak kesadaran keagamaan sebagai "kritik diri" dalam membaca Islam yang terlanjur membatu berabad-abad lamanya.

Bagi Jamâl al-Bannâ, dua paradigma berpikir di atas mempunyai kekurangan. Jika yang pertama terlalu menitikberatkan kepada pemahaman klasik dan harus didekonstruksi karena sifatnya yang jumûd, maka rekonstruksi tafsîr yang diusung tidak boleh terlalu mengilmiahkan al-Qur'an. Baginya, ada dimensi seni (irfânî) dalam al-Qur'an yang harus diresapi sebagai pondasi awal dalam mempersiapkan diri untuk menafsirkan al-Qur'an. Dimensi itulah yang nanti akan memberikan ruang spiritualitas manusia dalam bentuk kokohnya keimanan.

${ }^{44}$ Selengkapnya lihat Jamâl al-Bannâ, Tafsîr al-Qur'ân al-Karîm mâ bayn al-Quddâmâ wa al-Muhaddithîn (Kairo: Dâr al-Shurûq, 2008), h. 218-245.

${ }^{45}$ Abû Zayd, Ishkâlîyât al-Qirâ'ah, h. 13. 
Dalam metodologi studi al-Qur'an yang dikonstruksi, Jamâl al-Bannâ menekankan pentingnya makna al-Qur'an menjadi media revolusi peradaban manusia yang berkeimanan. Jamâl tidak menegaskan satu metode tertentu untuk menafsirkan al-Qur'an dan tidak membatasi ilmu atau metode apapun, atau bahkan anti metode, untuk membaca al-Qur'an. Ia menolak jika satu metode tertentu dianggap mempunyai garansi sebagai satu-satunya cara menemukan kebenaran. Apa saja dan siapa pun boleh untuk menafsir, selama hal itu secara aksiologis diorientasikan untuk memupuk kesadaran imaniah seseorang. Hal ini jugalah yang mendasari Jamâl al-Bannâ untuk menempatkan hikmah sebagai sumber ketiga Islam, karena sifatnya yang fleksibel dalam membangun pola pikir yang otonom, humanis, dan berbasis kemaslahatan manusia. Bahwa penafsir harus menguasai ilmuilmu kekinian, setidaknya berbagai teori-teori, ilmu sejarah, ilmu sosiologi, ilmu ekonomi, maupun ilmu politik itu sudah menjadi kerangka referensial mutlak bagi seorang penafsir dalam membaca teks al-Qur'an. ${ }^{46}$

Apa yang diusung oleh Jamâl al-Bannâ adalah hal yang sangat penting secara teoretis jika dilihat dari perspektif sosiologi pengetahuan ${ }^{47}$, mengingat otonomi manusia sekaligus perkembangan ilmu pengetahuan juga terus mengalami evolusi. Bagaimanapun, paradigma baru ilmu-ilmu keislaman merupakan persoalan tersendiri yang tidak mudah diselesaikan. Konstruksi teoretis Jamâl al-Bannâ ini sesungguhnya sangat kental dengan nuansa pemikiran yang dikembangkan oleh Paul K. Feyerabend yang terkenal dengan Anarkisme Metode. ${ }^{48}$

Istilah anarkis menunjuk pada setiap gerakan protes terhadap segala bentuk kemapanan. Anarkisme epistemologis yang dimaksudkan oleh Feyerabend adalah anarkisme teoretis dengan alasan historis bahwa sejarah ilmu pengetahuan tidak hanya bermuatan fakta dan kesimpulan-kesimpulannya, tetapi juga bermuatan gagasan-gagasan dan interpretasi. Beradasarkan analisis historis kritis, ia menemukan bahwa oleh para ilmuwan, fakta hanya

${ }^{46}$ al-Bannâ, al-Awdah, h. 94.

${ }^{47}$ Lihat Mannheim, Ideologi dan Utopia, h. 287.

${ }^{48}$ Walaupun kedua sosok ini tidak terkait satu sama lain, namun secara sosiologis karakter keduanya tidak jauh berbeda, sama-sama sebagai pemberontak, pendukung kebebasan, serta anti kemapanan terhadap siklus kehidupan yang mapan. Jika Feyerabend pada umur lima tahun, misalnya, sudah melarikan diri dari rumah. Karakter emosi yang sedemikian rupa secara tidak langsung memengaruhi keberpihakan intelektualnya dalam bingkai philosophy of science. Secara sederhana, tentu kita bisa menerima pendapat a priori yang menyatakan bahwa, seorang pribadi emosional cenderung lebih mudah bertindak anarkis ketimbang orang lain yang tidak emosional. Jika asumsi ini benar, maka, terdapat korelasi antara emosionalitas pribadi Feyerabend dengan kecenderungan anarkis dalam aras epistemologi. Selain itu, tindakan melarikan diri dari rumah, semakin menguatkan asumsi awal bahwa, ia sangat mengedepankan kebebasan dirinya. Lihat Qusthan Abqary, Melawan Fasisme Ilmu (Jakarta: Kelindan, 2009), h. 22. Sebanding dengan sosok Jamâl al-Bannâ yang tidak menyukai aturan-aturan yang mengikat, dimulai dengan keengganannya mengikuti aturan guru Bahasa Inggrisnya yang berujung kepada boikotnya meneruskan sekolahnya sampai penolakan dia terhadap ajakan Hasan al-Bannâ masuk kepada organisasi al-Ikhwân al-Muslimûn. 
ditinjau dari dimensi ide belaka. Maka tidak mengherankan jika sejarah ilmu pengetahuan menjadi pelik, rancu, dan penuh kesalahan. ${ }^{49}$

Secara garis besar, ada dua buah prinsip yang ditawarkan oleh Feyerabend, yakni prinsip pengembangbiakan (proliferation) dan prinsip apa saja boleh (anything goes). Adapun yang pertama, pengembangbiakan, sebenarnya bukan aturan metodologis melainkan suatu prinsip bahwa kemajuan ilmu pengetahuan tidak dapat dicapai dengan mengikuti metode atau teori tunggal. Kemajuan ilmu pengetahuan akan dicapai dengan membiarkan teoriteori yang beraneka ragam dan berbeda satu sama lain berkembang sendiri-sendiri. Sedangkan prinsip kedua apa saja boleh berarti membiarkan segala sesuatu berlangsung dan berjalan tanpa banyak aturan. Semua metode, termasuk yang paling jelas sekalipun pasti memiliki keterbatasan, sehingga tidak harus dipaksakan untuk menyelidiki semua objek. Apabila produk tafsîr bertujuan menguatkan akidah seseorang tentang Tuhan beserta rahasiaNya, maka persoalan menguatkan iman sesungguhnya tidak bisa diatur oleh siapa pun, karena keimanan, sebagai implikasi dari akidah, membutuhkan proses. ${ }^{50}$

Pemikiran Feyerabend ini berimplikasi pada pengembangan ilmu pengetahuan, bahwa dalam pengembangan alangkah baiknya seorang ilmuan ketika melakukan penelitian membebaskan diri dari metode-metode yang ada, meskipun terbuka kemungkinan menggunakan metode itu. Tidak ada metode tunggal. Setiap ilmuwan perlu menerapkan pluralitas teori, sistem pemikiran sesuai dengan kecenderungan masing-masing, karena setiap orang memiliki pilihan. ${ }^{51}$

Prinsip ini sejalan dengan pandangan Jamâl al-Bannâ bahwa setiap manusia/mujtahid dapat secara sadar memaknai doktrin-doktrin Islam sesuai dengan pengalaman keagamaan dan situasi sosialnya sendiri. Dengan begitu, maka orang tidak lagi saling mengkafirkan dan merasa dirinya benar. Apalagi, pluralisme teori ataupun pluralitas metodologi dalam segala riset studi Islam dapat dibenarkan untuk dilakukan.

Apabila mengacu kepada probem teologis dalam upaya memahami doktrin-doktrin al-Qur'an, terutama pada wilayah akidah, maka bagi Jamâl al-Bannâ persoalan menguatkan iman sesungguhnya tidak bisa diatur oleh siapa pun, karena keimanan, sebagai implikasi dari akidah, membutuhkan proses. ${ }^{52}$ Begitu juga dengan pemberlakuan sharî‘ah (tathbîq al-sharî‘ $a h)$. Maka dari itu, dari keinginan (akidah) ke praktik (sharî́ah) sangat bergantung kepada kesiapan individu dalam memupuk kesadaran imaniahnya, tanpa ada pretensi

${ }^{49}$ Prasetya T.W., "Hakikat Pengetahuan dan Cara Kerja Ilmu-Ilmu", dalam Tim Redaksi Driyarkara (Jakarta: Gramedia, 1993), h. 54.

${ }^{50}$ Jamâl al-Bannâ, Hal Yumkin Tathbîq al-Sharî́ah (Kairo: Dâr al-Fikr al-Islâmî, 2005), h. 53.

${ }^{51}$ Paul Karl Feyerabend, "How to be a Good Empiricist", dalam Brody, Barucho, Grandy, A. Richard, Reading in the Philosophy of Science (New Jersey: Prentince Hall Engleewood Clifft, 1989), 105. Dikutip dari Sarjuni, "Anarkisme", h. 158.

${ }^{52}$ al-Bannâ, Hal Yumkinu, h. 53. 
orang lain. ${ }^{53}$ Bukankah Allah itu memberi petunjuk kepada siapa pun yang dikehendakiNya? Bukankah Dia sendiri berfirman, "Apakah engkau [Muhammad] memaksa manusia sehingga mereka beriman?"54

Upaya membaca Jamâl al-Bannâ melalui kacamata Paul Karl Feyerabend didasarkan atas kesamaan prinsip apa saja boleh dalam riset-riset keilmuan. Semua itu dipraktikkan oleh Jamâl al-Bannâ dalam metodologi tafsirnya. Setelah melakukan pendekatan rasa dan psikologis, selanjutnya rasionalisasi pemahaman teks-teks keagamaan bersifat anarkis dan apa saja boleh, semuanya berbasis kebutuhan dan kemaslahatan. Tidak hanya tafsir, nuansa anarkistis dapat dijumpai dalam pemikiran segenap pemikiran Jamâl al-Bannâ baik dalam bidang fikih dan teologi. Bahkan dengan prinsip anarkistisnya, Jamâl mampu menyejajarkan kedudukan laki-laki dan perempuan. ${ }^{55}$

Artinya, metode penafsiran Jamâl al-Bannâ ingin mengajak siapa pun untuk dapat menjadi seorang mujtahid, dengan metode apa saja dan kapan saja. Dengan kata lain, metode pengembangan studi Islam, baik tafsîr, teologi, maupun fikih, dapat dilakukan dengan cara atau pendekatan apapun. Setiap orang bebas dan boleh mengikuti kecenderungannya melakukan usaha kritis memahami tafsîr sehingga ia mampu mencapai tingkat keyakinan yang lebih tinggi. ${ }^{56}$

Berdasarkan prinsip kebebasan ini, pengembangan tafsîr menjadi tugas yang tidak pernah berakhir. Penelitian untuk pengembangan tafsîr harus dilakukan secara terusmenerus. Sebagai ilmu, disiplin keilmuwan Islam—baik tafsîr, fikih, teologi, dan lainlain-tidak bisa melepaskan diri dari teori Brown yang mengatakan bahwa pengembangan suatu ilmu harus melalui continuing research. ${ }^{57}$ Pandangan Brown ini menjadi dasar bahwa pengembangan ilmu-ilmu Islam harus dilakukan terus-menerus dengan mengerahkan segala upaya termasuk menggunakan disiplin ilmu lain dan keragaman metodenya demi terwujudnya penafsiran yang dinamis dan hidup.

Berpijak pada kebebasan metodis ini, sosiologi pengetahuan bermanfaat bagi pengayaan metodis penelitian ilmu-ilmu Islam, tidak terkecuali tafsîr. Seperti argumentasi Jamâl, studi Islam sudah selayaknya dilihat dengan berbagai cara (apa saja boleh) sesuai dengan

${ }^{53}$ Jamâl al-Bannâ, Tathwîr al-Qur'ân (Kairo: Dâr al-Fikr al-Islâmî, 2000), h. 110; bandingkan al-Bannâ, Hal Yumkinu, h. 52-53.

${ }^{54}$ al-Bannâ, al-Mashrû‘ al-Hadârî, h. 26.

${ }^{55}$ Ia mendefinsikan perempuan dengan "al-insân awwalan wa unthâ thâniyan" [pertama sebagai manusia, dan yang kedua adalah perempuan]

${ }^{56}$ Prasetya, "Hakekat Pengetahuan", 57; Sarjuni, "Anarkisme Epistemologis", h. 156.

${ }^{57}$ Harold I. Brown, Perception, Theory and Commitment: The New Philosophy of Science (Chicago: The University of Chicago Press, 1979), 166. Dikutip dari Muhyar Fanani, Metode Studi Islam: Aplikasi Sosiologi Pengetahuan sebagai Cara Pandang (Yogyakarta: Pustaka Pelajar, 2008), h. 124. 
MIQOT Vol. XXXVIII No. 2 Juli-Desember 2014

perkembangnnya, ${ }^{58}$ asalkan semua cara itu dilakukan dengan bertanggung jawab dan dapat memperluas perspektif para pengkaji.

\section{Penutup}

Metode pembaruan penafsiran Jamâl al-Bannâ dimunculkan karena situasi sosial di Mesir, Timur-Tengah, dan dunia Islam pada umumnya yang terlihat tiranik dan jauh dari nuansa demokratis. Absolutisme mewabah ke seluruh sudut kehidupan, baik dalam bentuk rezim penguasa yang otoriter (mulk 'adûd atau Islâm al-sultân) maupun para agamawan yang otoriter. ${ }^{59}$

Secara garis besar, dalam rangka mengatasi krisis ini, Jamâl mengusulkan dua hal sebagai manifesto Muslim kontemporer. Pertama, membangun sistem pengetahuan yang baru sehingga umat Islam kembali membaca al-Qur'an dan sunnah dengan berpijak kepada kaca pandang keilmuan yang berjalan pada masa kontemporer.

Dalam kerangka ini, Jamâl yang dikenal sebagai pemikir humanis (the humanitarian thinker) sesungguhnya dipengaruhi oleh cita-cita kemanusiaan universal yang termuat dalam Islam. Tidak bisa dipungkiri bahwa kesadaran akan kekhasan manusia, kesamaannya, keluhuran dan keterbatasannya sebagai ciptaan mendapat penajaman dalam Islam. Di hadapan Allah, seseorang-baik budak atau bebas, terdidik atau tidak terdidik, pria wanita dan kaya miskin - tidak akan menentukan mutunya sendiri sebagai manusia.

Dalam rangka melapangkan jalan bagi terwujudnya tafsir humanis, hal pertama yang dilakukan Jamâl adalah menciptakan paradigma baru bagi pemahaman agama, khususnya teks al-Qur'an. Dalam banyak bukunya, sebagaimana telah disebutkan di depan, ia menegaskan bahwa al-Qur'an harus dipahami sesuai dengan sistem pengetahuan revolusioner yang dicapai oleh umat manusia. Artinya, al-Qur'an tidak boleh dipahami dengan menggunakan sistem pengetahuan yang sudah kadaluarsa.

Permasalahan-permasalahan sosial yang tengah dialami masyarakat Mesir, TimurTengah, dan dunia Islam pada umumnya, menurut Jamâl, muncul karena umat Islam selama ini terbelenggu oleh sistem pengetahuan lama sehingga mereka salah dalam memahami agama yang seharusnya merupakan rahmat dan solusi atas semua problem tersebut. Dari situlah Jamâl terdorong untuk menciptakan paradigma dan konsepsi baru dalam memahami Islam. Ketakberpihakan Jamâl terhadap satu metode apapun atau anarkisme metode atas nama humanitas, dalam konstruksi penulis, adalah salah satu dari konsepsi barunya dalam wilayah pemikiran Islam.

Anarkisme metode merupakan upaya kreatif Jamâl untuk memasukkan unsur

\footnotetext{
${ }^{58}$ Jamâl al-Bannâ, al-Mashrû‘ al-Hadârî li Da'wah al-Ihyâ' al-Islâmî (Kairo: Dâr al-Fikr alIslâmî, t.th.), 44.

${ }^{59}$ Ibid., h. 21.
} 
utama masyarakat modern, yakni kebebasan dan demokrasi ke dalam struktur pemikiran Islam. Dengan demikian, studi Islam diharapkan dapat menjadi pengetahuan yang demokratis dan modern. Jamâl menyadari bahwa untuk memodernisir pemikiran Islam tidak mungkin berhasil tanpa membebaskan perangkat metodisnya kepada siapa pun. Hal ini disebabkan karena semua klaim teori tertentu sebagai satu-satunya metode dalam menjangkau kebenaran sudah tidak lagi mampu mewujudkan tuntutan semua orang dan masa. Anarkisme metode dimaksudkan oleh Jamâl sebagai prinsip baru, untuk tidak mengatakan sebagai perangkat metodis yang rigid, dalam upayanya membebaskan manusia dalam menelaah pemikiran Islam di semua masa dan tempat.

Anarkisme metode merupakan bagian yang tidak terpisahkan dari upaya Jamâl untuk merekonstruksi sistem pengetahuan Islam, dari yang semula yang berorientasi teosentris (ketuhanan) menjadi antroposentris (kemanusiaan) yang dinamis, demokratis, dan tetap mengindahkan titah Tuhan. Titah Tuhan tersebut oleh Jamâl kemudian diperas sedemikian rupa sehingga hanya berbentuk prinsip-prinsip universal. Dengan demikian, anarkisme metode merupakan perpaduan antara kebebasan manusia dan wahyu Tuhan. Ia merupakan hasil dialektika antara keduanya. Anarkisme metode merupakan teori khas Jamâl untuk menciptakan sistem pengetahuan Islam menjadi sistem tafsir yang humanis.

\section{Pustaka Acuan}

A. F. Chalmers. Apa itu yang Dinamakan Ilmu? Suatu Penilaian tentang Watak dan Status Ilmu serta Metodenya, terj. Redaksi Hasta Mitra. Jakarta: Hasta Mitra, 1983.

A’la, Abd. Dari Neo Modernisme ke Islam Liberal. Jakarta: Dian Rahmat, 2009.

Abqary, Qusthan. Melawan Fasisme Ilmu. Jakarta: Kelindan, 2009.

Abû Zayd, Nasr Hâmid. Ishkâlîyât al-Qirâah wa Âlîyât al-Ta'wîl. Beirut: Markaz al-Thaqâfî, 1994.

Agger, Ben. Teori Sosial Kritis. Yogyakarta: Kreasi Wacana, 2003.

al-Bannâ, Jamâl. al-Aslân al-Azîmân "Al-Qur'an wa al-Sunnah”: Ru'yah Jadîdah. Kairo: Matba'ah Hisân,-1982. -

al-Bannâ̄, Jamâl. al-Awdah ilâ al-Qur'an. Kairo: Dâr al-Shurûq, 2008.

al-Bannâ, Jamâl. al-Mashrû' al-Hadârî li Da'wah al-Ihyâ' al-Islâmî. Kairo: Dâr al-Fikr alIslâmî, t.t.

al-Bannâ, Jamâl. Hâ Huwa Dhâ al-Barnâmij al-Islâmî. Kairo: Dâr al-Fikr al-Islâmi, 1991. al-Bannâ, Jamâl. Hal Yumkin Tatbîq al-Sharî‘ah. Kairo: Dâr al-Fikr al-Islâmî, 2005.

al-Bannâ, Jamâl. Mâ ba'd al-Ikhw̄wân al-Muslimîn. Kairo: Dâr al-Fikr al-Islâmî, 1996.

al-Bannâ, Jamâl. Nahw Fiqh Jadîd: Muntaliqât wa Mafâhîm: Fahm al-Khitâb al-Qur'anî, Vol. 1. Kairo: Dâr al-Fikr al-Islâmî,-1996.

al-Bannâ, Jamâl. Tafsîr al-Qur'an al-Karîm mâ bayn al-Quddâmâ wa al-Muhaddithîn. Kairo: Dâr al-Shurûq, 2008. 
MIQOT Vol. XXXVIII No. 2 Juli-Desember 2014

al-Bannâ, Jamâl. Tajdîd al-Islâm wa I'âdat Ta'sîs Manzûmat al-Ma'rifah al-Islâmîyah. Kairo: Dâr al-Fikr al-Islâmî, 2005.

al-Bannâ, Jamâl. Tathwîr al-Qur'an. Kairo: Dâr al-Fikr al-Islâmî, 2000.

Brown, Harold I. Perception, Theory and Commitment: The New Philosophy of Science. Chicago: The University of Chicago Press, 1979.

Ensiklopedi tokoh yang memuat profil ibunda Hasan al-Bannâ dalam www.egyptwindow.net/ nafidatumasr/07-08-2007

Fanani, Muhyar. Metode Studi Islam: Aplikasi Sosiologi Pengetahuan sebagai Cara Pandang. Yogyakarta: Pustaka Pelajar, 2008.

Feyerabend, Paul Karl. "How to be a Good Empiricist", dalam Brody, Barucho, Grandy, A. Richard, Reading in the Philosophy of Science. New Jersey: Prentince Hall Engleewood Clifft, 1989.

Hardiman, F. Budi. Kritik Ideologi: Pertautan Pengetahuan dan Kepentingan. Yogyakarta: Kanisius, 1990.

Hardiman, F. Budi. Melampaui Positivisme dan Modernitas: Diskursus Filosofis tentang Metode Ilmiah dan Problem Modernitas. Yogyakarta: Kanisius, 2003.

Hidayatullah, Syarif. Intelektualisme dalam Perspektif Neo-Modernisme. Yogyakarta: Tiara Wacana, 2000.

http://ar.wikipedia.org/wiki/Jamâl_al_Banna

Karam, Yûsuf. Târîkh al-Falsafah al-Hadîthah. Kairo: Dâr al-Ma'ârif, Cet. Ke-5, 1986.

Lee, Robert D. Mencari Islam Autentik: Dari Nalar Puitis Iqbal hingga Nalar Kritis Arkoun, terj. Ahmad Baiquni. Bandung: Mizan, Cet. Ke-2, 2000.

Magnis-Suseno, Franz. Filsafat Sebagai Ilmu Kritis. Yogyakarta: Kanisius, 1992.

Magnis-Suseno, Franz. Pijar-Pijar Filsafat: Dari Gatholoco ke Filsafat Perempuan, dari Adam Muller ke Postmodernisme. Yogyakarta: Kanisius, 2005.

Mannheim, Karl. Ideologi dan Utopia: Menyingkap Kaitan Pikiran dan Tindakan, terj. F. Budi Hardiman. Yogyakarta: Kanisius, 1998.

Mansur, M. "Metodologi Penafsiran Realis ala Hassan Hanafi” dalam Jurnal al-Qur'an dan Hadits, Vol. 1, No. 1. Yogyakarta: Fakultas Ushuluddin IAIN Sunan Kalijaga, 2000.

Mustaqim, Abdul Epistemologi Tafsir Kontemporer. Yogyakarta: LKiS, 2010.

Sâlih, Hâshim. "Jamâl al-Bannâ... Bayn al-Islâh al-Dînî wa al-Tanwîr" dalam www.assyarqalawsat. com/24-Mei-2004.

Sarjuni. "Anarkisme Epistemologis Paul Karl Feyerabend", dalam Listiyono Santoso dkk, Epistemologi Kiri. Yogyakarta: ar-Ruzz, 2003.

T.W., Prasetya. "Hakikat Pengetahuan dan Cara Kerja Ilmu-Ilmu”, dalam Tim Redaksi Driyarkara. Jakarta: Gramedia, 1993.

Zaqzûq, Mahmûd Hamdî. Dirâsât fî al-Falsafah al-Hadîthah. Kairo: Dâr al-Fikr al-'Arabî, 1993. - 